\title{
Cues in salt marshes stimulate molting of fiddler crab Uca pugnax megalopae: more evidence from field experiments
}

\author{
Nancy J. O'Connor ${ }^{1, *}$, Michael L. Judge ${ }^{2}$ \\ ${ }^{1}$ Department of Biology, University of Massachusetts Dartmouth, N. Dartmouth, Massachusetts 02747-2300, USA \\ ${ }^{2}$ Department of Biology, Manhattan College, Riverdale, New York 10471, USA
}

\begin{abstract}
Most marine benthic invertebrates possess complex life histories that involve a planktonic larval stage that must seek the proper adult habitat. For practical reasons, the search for cues that stimulate settlement and metamorphosis to the benthic stage have traditionally utilized either laboratory studies or field correlations between larval and adult distributions. In contrast, we have developed an in situ technique that employs lab-reared fiddler crab Uca pugnax larvae placed in mesh cages in realistic estuarine settings to address the roles of potential adult habitat cues for molting. We extended our prior work to examine the influence of sediment type on molting of megalopae. In addition, we manipulated the duration of field exposure of megalopae to cues. In 2 series of experiments (1996 and 1997), we examined the importance of the nature of cues (waterborne vs sediment), habitat (sandflat vs salt marsh), duration of exposure to field cues (1 vs $3 \mathrm{~d}$ ), and field test site (different marshes within an estuary). Freshly collected marsh sediment stimulated molting to the benthic first crab stage, whereas fresh sand did not. Contact with natural seawater overlying a marsh also stimulated molting compared to control megalopae in filtered seawater in the lab or field. Moreover, the response appeared additive: the highest molting rates were observed when megalopae were exposed to both marsh sediment and seawater. Cages on the sandflat remained intact but filled with sediment, and almost all megalopae died before molting. Three days of field exposure to marsh sediments and seawater had a greater effect on molting than $1 \mathrm{~d}$ of exposure, although megalopae were stimulated to molt following only the $1 \mathrm{~d}$ exposure period. In addition, results were consistent in marshes that differed in sediment particle size. Consistency in response among years and between marsh sites suggests a strong response of fiddler crab megalopae to natural marsh ecosystems.
\end{abstract}

KEY WORDS: Fiddler crab $\cdot U_{c a}$ pugnax $\cdot$ Larvae $\cdot$ Molting $\cdot$ Metamorphosis $\cdot$ Chemical cues

\section{INTRODUCTION}

The transition from a pelagic to a benthic lifestyle is a critical period for marine organisms with complex life histories. If larvae settle in habitats unsuitable for juvenile or adult stages, they may incur a lowered probablility of survival. Consequently, larvae of many species possess neurological systems capable of detecting, assessing, and responding to the apparent suitability of an environment for benthic phases of the life cycle (reviewed by Burke 1983). Chemical, physical, or hydrodynamic variables may influence the suitability

•E-mail: noconnor@umassd.edu of a habitat (reviewed by Meadows \& Campbell 1972, Crisp 1974, Morse 1990, Pawlik 1992, Rodriguez et al. 1993, Abelson \& Denny 1997).

Several techniques are employed to determine the relative frequency of larval settlement and metamorphosis under various conditions. Laboratory experiments provide information about responses to individual cues, in conditions of still or moving water (reviewed by Scheltema 1974, Butman 1987), but they may lack the realisms of variables naturally interacting in the field. Intensive field sampling allows one to compare the spatial patterns of larval settlement with patterns of juvenile and adult abundance (reviewed by Hunt \& Scheibling 1997), or patterns of larval settle- 
ment on natural or manipulated substrata (e.g. Eckman 1983, Levin 1984, Gaines et al. 1985, Wethey 1986, Raimondi 1988). However, a lack of settlers at a particular location could not distinguish between paucity of larvae and that larvae contacted the area but chose not to settle and metamorphose there and returned to the water column (Butman 1987). If no settled larvae are found in a particular area, it is very difficult to differentiate between these 2 causal explanations. In addition, whether larvae that did settle had prior exposure to cues that could influence their propensity for settlement and metamorphosis is unknown. Therefore, it is important to determine the response of larvae, preferably of known age and experience, to potential habitat cues under realistic, natural conditions

One way of doing this is to present larvae with natural cues by enclosing them in mesh cages in the field, a technique we developed and tested previously (O'Connor \& Judge 1997). Our initial experiments demonstrated that, for fiddler crab UCa pugnax megalopae, both waterborne cues in seawater overlying a marsh containing conspecifics and natural sediments from the marsh stimulated molting (metamorphosis) of megalopae to the benthic first crab stage. In the work reported here, we performed 2 additional field experiments to (1) address the potential role of a sandflat habitat and sandflat sediment cues in stimulating molting, (2) vary the duration of the field exposure period, and (3) determine whether results are similar between marsh habitats and years. The results of the experiments extend our prior work: megalopae responded to both marsh sediments and waterborne cues overlying the marsh, by molting earlier to the benthic crab stage compared to megalopae in control treatments. The duration of field exposure influenced the magnitude of the response. Sandflat cues did not influence molting. In addition, megalopae responded similarly to cues in different marshes.

\section{MATERIALS AND METHODS}

Larval culture. Larvae used in the experiments were obtained from ovigerous female Uca pugnax collected from the Slocums River estuary in Dartmouth, Massachusetts, USA (salinity approx. 30). Individual ovigerous crabs were placed in $11.5 \mathrm{~cm}$ glass culture dishes with $-200 \mathrm{ml}$ filtered $(0.45 \mu \mathrm{m})$ seawater diluted with distilled water to a salinity of 25 (= FSW), to which the antibiotics sodium penicillin $\mathrm{G}\left(21.9 \mathrm{mg} \mathrm{l}^{-1}\right)$ and streptomycin sulfate $\left(36.5 \mathrm{mg} \mathrm{l}^{-1}\right)$ were added. The dishes were checked every morning for the presence of larvae. Ovigerous females were transferred to a clean bowl with fresh FSW and antibiotics each day until larvae hatched.
Groups of $\sim 40$ newly released sibling zoeae were placed in each of three or four $11.5 \mathrm{~cm}$ culture dishes containing $\sim 175 \mathrm{ml}$ of FSW and antibiotics. Rotifers Brachionus plicatilis and newly hatched brine shrimp nauplii Artemia sp. were offered as food. As the zoeae molted to later stages, the proportion of rotifers in their diet was decreased, and that of Artemia sp. was increased, so that by the fourth zoeal stage, the larvae were fed brine shrimp only. Each day, the larvae were transferred to clean dishes with fresh FSW and antibiotics, and food was added. The number of deaths and the approximate proportion of animais molting were recorded. Mortality of zoeae during rearing was generally very low $(<5 \%)$, and larvae usually molted synchronously. Ovigerous females and larval cultures were maintained in an environmental chamber $(26 \pm$ $1^{\circ} \mathrm{C}, 14 \mathrm{~h}$ light: $10 \mathrm{~h}$ dark photoperiod).

After molting to the megalopa stage, 11 to $12 \mathrm{~d}$ after hatching, the larvae were cultured in groups of -80 to 100 in $20 \mathrm{~cm}$ glass culture dishes containing $600 \mathrm{ml}$ FSW, antibiotics, and Artemia sp. nauplii. Megalopae were transferred to clean dishes and fed each day. Megalopae were used in the field experiments $6 \mathrm{~d}$ after they had molted to the megalopa stage.

Cage design. Cylindrical cages $(10 \mathrm{~cm}$ height $\times 8.8 \mathrm{~cm}$ width) were used for field deployment of lab-reared larvae. The base of the cage consisted of the bottom portion ( $8.8 \mathrm{~cm}$ width $\times 1.4 \mathrm{~cm}$ height) of a polystyrene petri dish (Baxter D1906 in 1996 and VWR 25384-070 in 1997). The sides and top of the cages were made of $300 \mu \mathrm{m}$ nylon mesh. The top contained a sealable flap that opened halfway to allow addition of megalopae in the field. All seams of the cage were glued with $100 \%$ silicone sealant (G.E. [General Electric] no. 012). A $20 \mathrm{~cm}$ mild steel (high carbon) stake was glued with silicone to the outside of the petri dish bottom to secure the cage in marsh sediments. Cages in the sandflat in 1996 had 3 steel stakes glued to the complementary half of the petri dish, which was buried in the sand and served to anchor the cage securely.

Field sites. Two field sites were chosen near the mouth of the Slocums River. The field site in 1996 was a marsh consisting of Spartina alterniflora and Salicornia europaea growing in muddy sand sediments ( $75 \%$ particles $>63 \mu \mathrm{m})$, located in Demarest Lloyd State Park near the mouth of the Slocums River estuary $\left(41^{\circ} 32^{\prime} \mathrm{N}\right.$, $70^{\circ} 59^{\prime} \mathrm{W}$, Fig. 1). The marsh contained numerous burrows occupied by the fiddler crab Uca pugnax. Adjacent to the marsh was an unvegetated intertidal sandflat. The 1997 field site was located approximately $0.9 \mathrm{~km}$ across the Slocums River from the 1996 field site (Fig. 1), at the Lloyd Center for Environmental Studies. The marsh was muddier (only $36 \%$ particles $>63 \mu \mathrm{m}$ ), and consisted of a broader expanse of $S$. alterniflora and a larger population of $U$. pugnax than the 1996 marsh habitat. 


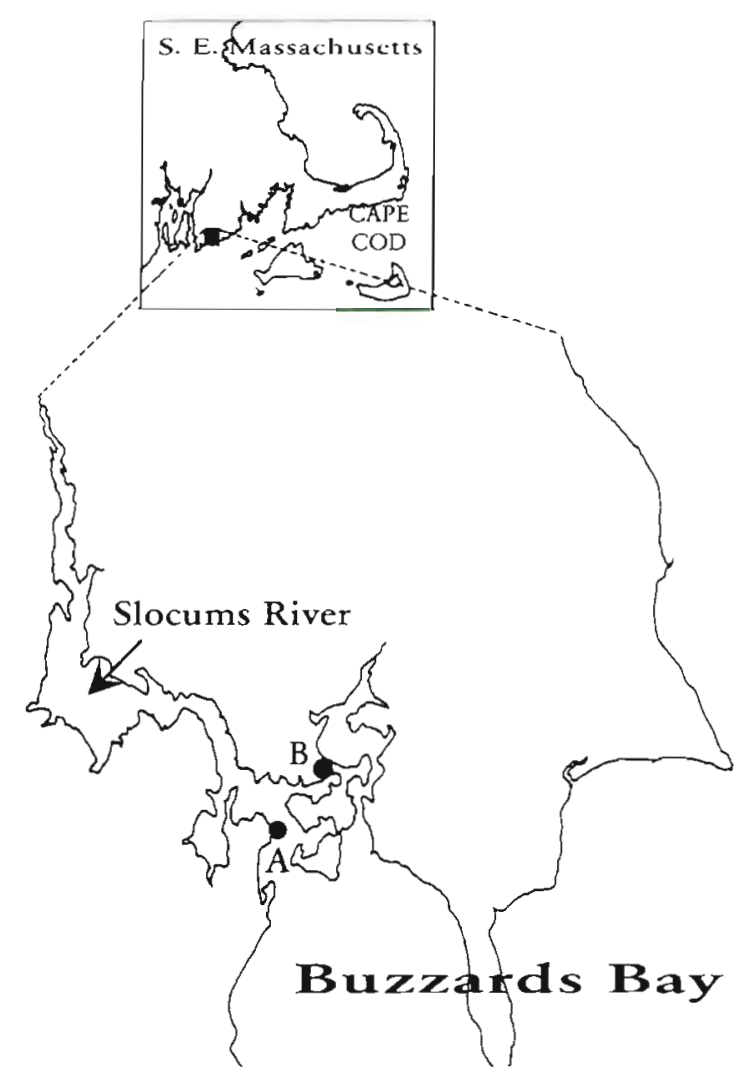

Fig. 1. Map of the field sites along the Slocums River estuary, Massachusetts. Field experiments in (A) 1996 and (B) 1997

Treatments and cage deployment 1996. Cages contained $15 \mathrm{ml}$ of sediments of 1 of 3 types: (1) surface ( $\sim 0.5 \mathrm{~cm}$ depth) marsh sediments collected near fiddler crab burrows on the day the experiment began (= fresh marsh sediments treatment), and (2) identical marsh sediments that had been collected earlier, dried, and combusted in a muffle furnace $\left(550\right.$ to $600^{\circ} \mathrm{C}$ for $\left.2 \mathrm{~h}\right)$ to oxidize organic material ( $=$ muffled marsh sediments treatment), or (3) surface $(-0.5 \mathrm{~cm}$ depth) sediments collected the day the experiment began from the sandflat adjacent to the marsh (= fresh sandflat sediments treatment). Large detrital fragments and pebbles were removed from all sediment types with forceps. All sediments were placed in cages in the field just prior to the time megalopae were introduced to the cages.

Within the marsh, 2 transects perpendicular to the shore were established in the marsh where crabs were abundant. Each transect was approximately $4 \mathrm{~m}$ long, at a tidal height of $0.83 \mathrm{~m}$. A total of 21 cages, $40 \mathrm{~cm}$ apart from each other, were placed along the 2 parallel transects. Treatments alternated between fresh marsh sediment, muffled marsh sediment, and fresh sandflat sediment treatments. All cages in the marsh were $\geq 5 \mathrm{~m}$ into the vegetated habitat.
An additional pair of transects was established in the sandflat, parallel to the shore and at the same intertidal elevation as the transects in the marsh. A PVC latticework was placed vertically in the sand approximately $50 \mathrm{~cm}$ seaward of the transect and anchored to reinforcing bars. The latticework was $40 \mathrm{~cm}$ high and $5 \mathrm{~m}$ long, and resulted in approximately $60 \%$ flow blockage

Three replicates of each sediment type were placed in each habitat on 17 July 1996, and 4 replicates of each sediment type were deployed on 18 July. In both cases, the experiment was initiated $6 \mathrm{~d}$ after Uca pugnax larvae reached the megalopa stage in lab cultures. Ten megalopae were placed in each replicate cage. In the laboratory, megalopae pooled from 5 different broods were divided into groups of 10 and placed in $12 \mathrm{ml}$ of FSW (salinity = 25) in polypropylene centrifuge tubes for transport to the field site. Some Artemia sp. nauplii were added to provide food for the megalopae. In addition, siblings of the megalopae exposed to field cues were maintained in the laboratory for a control treatment. Groups of 10 megalopae were placed into each of eight $8.5 \mathrm{~cm}$ glass dishes containing $60 \mathrm{ml} \mathrm{FSW} \mathrm{(without} \mathrm{antibiotics)} \mathrm{and} \mathrm{Artemia}$ sp. nauplii were added. The dishes were placed in an environmental chamber $\left(26 \pm 1^{\circ} \mathrm{C}, 14 \mathrm{~h}\right.$ light: $10 \mathrm{~h}$ dark), and the megalopae were transferred daily to clean dishes with fresh FSW and food.

Megalopae were introduced into each cage in the late afternoon, $-2.5 \mathrm{~h}$ prior to submersion by the incoming tide. Megalopae (and Artemia sp.) were rinsed from the centrifuge tube into the cage, using sieved, field-collected seawater. The flap opening at the top of the cage was then sealed with silicone.

Cages were monitored during daylight hours. One of the fresh sediment cages deployed on 17 July in the marsh was removed after $2 \mathrm{~d}$ of field exposure, and brought to the laboratory for intermediate assessment of molting frequency. All other cages were removed after $3 \mathrm{~d}$ of exposure, during which they were submerged approximately $34 \%$ of the time based on NOAA (1996) tidal predictions. In the laboratory, cages were cut open, emptied, and the contents were washed with FSW onto a $0.4 \mathrm{~mm}$ mesh sieve. Megalopae, first stage crabs, and sediments on the sieve were rinsed into petri dishes and examined using a lighted magnifier and a dissecting microscope. Megalopae and newly molted crabs from each cage were placed in $60 \times 15 \mathrm{~mm}$ petri dishes containing FSW. Dishes were then placed in an environmental chamber $\left(26 \pm 1^{\circ} \mathrm{C}, 14 \mathrm{~h}\right.$ light: $10 \mathrm{~h}$ dark).

Treatments and cage deployment 1997. Cages contained $15 \mathrm{ml}$ of sediments from the marsh, either freshly collected or muffled. Sediments were collected and prepared in an identical manner as in 1996. A lab- 
oratory control treatment consisted of 10 groups of 10 megalopae each placed in $11 \mathrm{~cm}$ glass dishes containing $200 \mathrm{ml}$ FSW (salinity $=30$ ) in an environmental chamber $\left(26 \pm 1^{\circ} \mathrm{C}, 14 \mathrm{~h}\right.$ light: $10 \mathrm{~h}$ dark). Seawater at the site typically has a salinity of 30 . We also added a field control treatment consisting of 10 replicate groups of 10 megalopae each placed in glass jars containing $200 \mathrm{ml} \mathrm{FSW}$. Jars were approximately $7 \mathrm{~cm}$ diameter and approximately $12 \mathrm{~cm}$ high, with a polyvinyl-lined plastic lid. The same nylon mesh used to construct the cages was wrapped around the outside of the jars to simulate light conditions inside the cages.

Two transects, each of approximately $11 \mathrm{~m}$ length, were established in the marsh. Cage and control treatments were interspersed regularly along the transects. Megalopae from 6 different broods were divided among the 4 treatments. All megalopae were deployed on 20 July, $0.5 \mathrm{~h}$ before immersion by flood tide. Megalopae were exposed to field conditions for either a $1 \mathrm{~d}$ period (20 to 21 July 1997, 10 replicates per treatment, $32 \%$ submergence time) or a 3 d period (20 to 23 July 1997, 10 replicates per treatment except 5 cages of the muffled sediment, $32 \%$ submergence time). An additional empty cage contained a temperature probe (Optic Stow Away, Onset Computers), which sampled and recorded ambient temperature at $40 \mathrm{~s}$ intervals, and an extra jar contained a thermometer.

Cages and jars were retrieved during periods of low tide. Cages were processed and examined in a similar way as for the 1996 experiment. All megalopae and first stage crabs found were placed in $8 \mathrm{~cm}$ glass dishes containing $60 \mathrm{ml}$ FSW and Artemia sp. nauplii were added. After processing, dishes were placed in an environmental chamber $\left(26 \pm 1^{\circ} \mathrm{C}, 14 \mathrm{~h}\right.$ light: $10 \mathrm{~h}$ dark), and examined at daily intervals.

Data analysis. The proportion of megalopae molting to the first crab stage of those recovered alive was the response variable, with cages serving as replicates. Recovery rates of individuals deployed into the marsh field treatments were $92.9 \%$ (195 out of 210$)$ and $96.4 \%$ (520 out of 550) in 1996 and 1997, respectively. The molting response was analyzed on both Days 9 and 10 of the megalopal stage. After arcsine transformation, the variances were never found to differ significantly from homogeneity for either megalopal age or year of experiment (Bartlett's test, all p values $>0.72$ ).

In 1996, after the removal of the sandflat habitat treatment (see 'Results'), data were analyzed via 1-way ANOVA with sediment type as the main effect and deployment date as a blocking factor. Deployment date was an insignificant source of variability (ANOVA, $F_{1.23}<0.001, \mathrm{p}=0.997$ ). Planned a priori comparisons were conducted between the lab control and the field. cage treatments. In 1997, a 2-way ANOVA with sediment type and length of field exposure to cue was not possible due to a significant interaction term in the model. Thus, an overall statement for each main effect is unjustified. Instead, separate 1-way ANOVAs with either sediment or cue duration as the main effect were performed as suggested by Sokal \& Rohlf (1981).

\section{RESULTS}

\section{6 experiment}

Exposure to natural conditions in a salt marsh enhanced molting of Uca pugnax megalopae compared to control megalopae in the laboratory. After $3 \mathrm{~d}$ in the field (= Day 9 of the megalopal stage), a mean proportion of $0.60( \pm 0.26 \mathrm{SD})$ of megalopae in the fresh marsh sediment treatment in the field molted, whereas only $0.26( \pm 0.21)$ of megalopae in cages with muffled marsh sediments and $0.29( \pm 0.26)$ of megalopae in cages with fresh sand molted (Fig. 2). In control FSW in the laboratory, $0.29( \pm 0.22)$ of the megalopae had molted. In planned comparisons, only the fresh marsh sediment treatment was significantly different from the others (ANOVA, $0.025<\mathrm{p}<0.045$ ).

However, $1 \mathrm{~d}$ after termination of the experiment (= Day 10), the relative proportions of megalopae molting changed. Most $(\geq 0.86)$ of the megalopae exposed to natural seawater overlying the marsh had molted, regardless of the type of sediment to which they were exposed, compared to only half of controls in the laboratory (Fig. 2). All of the megalopae in cages in the field had higher rates of molting than controls in the laboratory (ANOVA planned comparisons, $\mathrm{p}<0.001$ in all cases). Therefore, fresh marsh sediments and natural marsh seawater both stimulated molting of fiddler

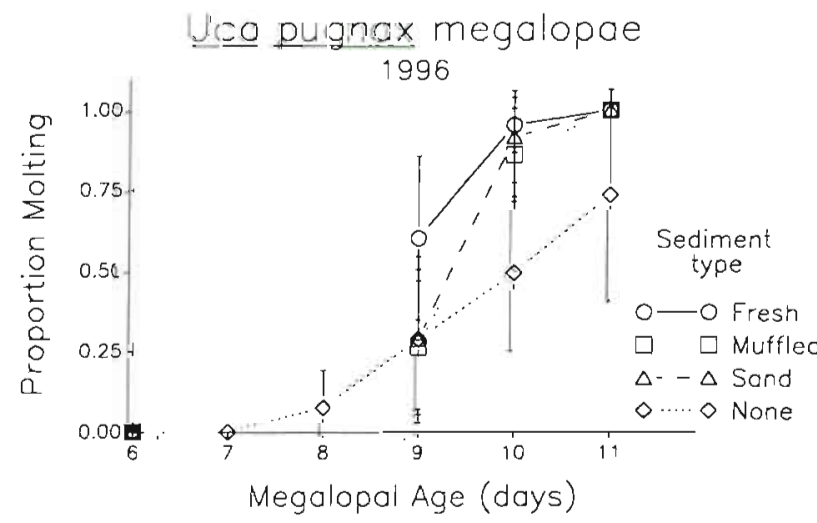

Fig. 2. Uca pugnax. Mean proportion of megalopae ( $\pm 1 \mathrm{SD}$ ) molting to the first crab stage in response to various sediment types during the course of the experiment (Fresh $=$ fresh marsh sediments: Muffled $=$ combusted marsh sediments; Sand $=$ fresh sandflat sediments; None = laboratory control filtered seawater). Megalopal age indicates days since molting to the megalopal stage 
crab megalopae, although molting was stimulated earlier in megalopae exposed to both types of cues.

Of the individuals in the cages in the marsh, $93 \%$ were recovered, and $94 \%$ of those had survived. However, only 1 individual (of 210) in cages on the sandflat was found alive, still in the megalopal stage. Although the cages remained upright, a large amount of sand was deposited in the cages, possibly burying the megalopae. Most megalopae found dead in the cages were badly damaged. The latticework, placed seaward of the cages in an attempt to buffer the waves, was found washed up on shore on 19 July. It was replaced, but on 20 July it was again missing and not recovered.

\section{7 experiment}

Because the 2-way ANOVA testing sediment type and length of field exposure to cue possessed a significant interaction term, we are forced to qualify the generality of each factor and describe the response to sediment type for each length of field exposure (Sokal \& Rohlf 1981). Nonetheless, it is clear that the interaction term arises from a synergism between the main effects (Fig. 3). That is, while the rank order among sediment type treatments remains virtually identical, the magnitude of the megalopal response in the $3 \mathrm{~d}$ field exposure to fresh sediments is greater than expected (i.e. additive). In large part, this interaction is a direct consequence of the low molting frequency in the control treatments (i.e. no sediment or waterborne cues).

Analyzing only the $1 \mathrm{~d}$ field exposure results, the effect of sediment on molting frequency was straightforward. No megalopae molted after $1 \mathrm{~d}$ of exposure to natural cues in the marsh. Two days after the $1 \mathrm{~d}$ field exposure (= Day 9), no overall significant differences existed in the mean proportion molting among treatments (Fig. 3, Table 1), although the planned comparison between fresh marsh sediment and the 3 other treatments was significant (Table 1). However, $3 \mathrm{~d}$ after the $1 \mathrm{~d}$ field exposure period (= Day 10 ), significantly more megalopae that were in cages with muffled marsh sediment ( $=$ muffled sediment treatment) molted to the first crab stage, compared to megalopae that were in jars containing FSW (= field control treatment) or lab FSW controls (Fig. 3, Table 1).

Megalopae in the field for $3 \mathrm{~d}$, in general, showed higher proportion molting and more differences among the treatments than those in the field for only $1 \mathrm{~d}$. At the end of the exposure period (= Day 9), the proportion of megalopae molting in cages with fresh sediment was significantly different from the number molting in cages with muffled sediment and control megalopae in jars of FSW in the field and in dishes of

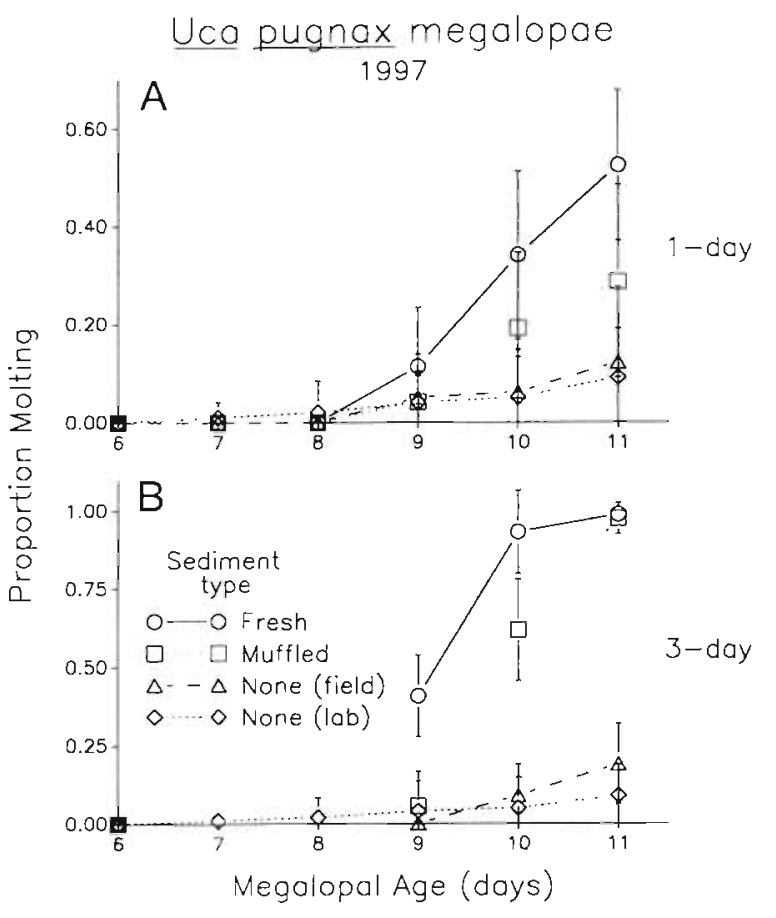

Fig. 3. Uca pugnax. Mean proportion of megalopae ( $\pm 1 \mathrm{SD}$ ) molting to the first crab stage in response to various sediment types during the course of the experiment [Fresh = fresh marsh sediments; Muffled = combusted marsh sediments; None (field) $=$ control filtered seawater in the field; None $($ lab) $=$ control filtered seawater in the laboratory]. Megalopal age indicates days since molting to the megalopal stage. (A) Results of a $1 \mathrm{~d}$ field exposure period. (B) Results of a $3 \mathrm{~d}$ exposure. Note that the $y$-axes of the 2 graphs differ

FSW in the laboratory (Fig. 3, Table 1). One day after termination of the experiment $(=$ Day 10$)$, planned comparisons showed that molting frequency was higher for megalopae that had been in the cages with muffled marsh sediment than for megalopae in control FSW in jars in the field or dishes in the laboratory (Fig. 3, Table 1). No differences were observed among control FSW in jars in the field or lab controls (Table 1). Differences in molting between the fresh sediment and muffled sediment treatments disappeared by Day 11 (Fig. 3). As in the 1996 experiment, megalopae exposed to both natural seawater and fresh marsh sediments molted earlier than megalopae exposed to natural seawater alone.

Temperatures within the cage varied with the pattern of submergence and exposure to air (Fig. 4). The temperature ranged from 16 to $25^{\circ} \mathrm{C}$, with a mean of $22^{\circ} \mathrm{C}$ during the $3 \mathrm{~d}$ field experiment. The probe responded rapidly $(<3 \mathrm{~min}$ ) to the change in temperature associated with the late afternoon flood tide (i.e. water temperature $>$ air temperature at this time of day). This responsiveness allowed phase alignment with tidal predictions for a NOAA tidal station (New- 
Table 1 UCa pugnax. Mean proportion $( \pm 1$. SD) of megalopae molting to the first crab stage in different sediment treatments (fresh, muffled) and controls (field, lab). ANOVA values for the overall sediment effect and planned comparisons for a given megalopal age are presented for each duration of field exposure $(" p<0.05, \cdots p<0.01, \cdots p<0.001)$

\begin{tabular}{|c|c|c|c|}
\hline \multirow{2}{*}{$\begin{array}{l}\text { Megalopal } \\
\text { age }\end{array}$} & \multicolumn{3}{|c|}{ Proportion molting to first crab stage } \\
\hline & Fresh Muffled & Field control & Lab control \\
\hline \multicolumn{4}{|l|}{ (A) 1 d field exposure } \\
\hline Day 9 & $0.11 \pm 0.12 \quad 0.04 \pm 0.05$ & $0.05 \pm 0.05$ & $0.04 \pm 0.10$ \\
\hline Overall sediment effect & \multicolumn{3}{|c|}{$F_{3,36}=1.82 \mathrm{~ns}$} \\
\hline Planned comparisons & & & \\
\hline Fresh vs all others & \multirow{3}{*}{\multicolumn{3}{|c|}{$\begin{array}{l}F_{1,36}=4.71^{\circ} \\
F_{1,36}=0.005 \mathrm{~ns} \\
F_{1,36}=0.68 \mathrm{~ns}\end{array}$}} \\
\hline Muffled vs controls & & & \\
\hline Field vs lab control & & & \\
\hline Day 10 & $0.34 \pm 0.17 \quad 0.19 \pm 0.15$ & $0.06 \pm 0.07$ & $0.05 \pm 0.10$ \\
\hline Overall sediment effect & \multicolumn{3}{|c|}{$F_{3,36}=9.15 \cdots$} \\
\hline Planned comparisons & & & \\
\hline Fresh vs all others & \multicolumn{3}{|l|}{$F_{1,36}=18.97^{\cdots}$} \\
\hline Muffled vs controls & \multicolumn{3}{|l|}{$F_{1,36}=8.10^{\prime}$} \\
\hline Field vs lab control & \multicolumn{3}{|l|}{$F_{1,36}=0.29 \mathrm{~ns}$} \\
\hline \multicolumn{4}{|l|}{ (B) 3 d field exposure } \\
\hline Overall sediment effect & \multicolumn{3}{|c|}{$F_{3,29}=37.60 \cdots$} \\
\hline Planned comparisons & \multirow{2}{*}{\multicolumn{3}{|c|}{$F_{10}=108.89 \cdots$}} \\
\hline Fresh vs all others & & & \\
\hline Muffled vs controls & \multicolumn{3}{|l|}{$F_{1.29}=0.84 \mathrm{~ns}$} \\
\hline Field vs lab control & \multicolumn{3}{|l|}{$F_{1.29}=1.69 \mathrm{~ns}$} \\
\hline Day 10 & $0.93 \pm 0.13 \quad 0.62 \pm 0.16$ & $0.09 \pm 0.10$ & $0.05 \pm 0.10$ \\
\hline Overall sediment effect & \multicolumn{3}{|c|}{$F_{3,29}=70.18 \cdots$} \\
\hline Planned comparisons & & & \\
\hline Fresh vs alj others & \multicolumn{3}{|l|}{$F_{1,29}=171.48 \cdots$} \\
\hline Muffled vs controls & \multicolumn{3}{|l|}{$F_{129}=37.29 \cdots$} \\
\hline Field vs lab control & \multicolumn{3}{|l|}{$F_{1,29}=1.28 \mathrm{~ns}$} \\
\hline
\end{tabular}

frequency of molting to the benthic crab stage (Fig. 3). Even only 1 d of exposure to fresh-collected sediments by naive megalopae stimulated molting $3 \mathrm{~d}$ later. Because 1 and $3 \mathrm{~d}$ experiments were conducted simultaneously, the stronger response observed suggests a dose-dependent response by the megalopae. That megalopae can respond just to the presence of a waterborne cue (muffled treatment) alone indicates that they may be able to detect appropriate adult habitat even without direct contact. For example, after $3 \mathrm{~d}$ exposure in the muffled treatment, virtually all megalopae by Day 11 had molted to the crab stage (Fig. 3). However, when direct contact with sediments was allowed, as would be true for Uca pugnax megalopae returning from the sea, molting frequency was advanced by at least $1 \mathrm{~d}$. By relying upon a combination of cues (both sediment and waterborne in this case), a megalopa would more likely make the correct 'molting decision' (O'Connor 1991). While we are able to show that naive megalopae are receptive to cues by Day 6 , we do not know how long the receptive 'window' exists (the data suggest longer than $1 \mathrm{~d}$ ) or the distance from a port, Rhode Island, USA; NOAA 1997). Thus, the temperature probe served as a surrogate for tidal submergence.

\section{DISCUSSION}

In the present experiments, and in a prior study (O'Connor \& Judge 1997), molting of Uca pugnax megalopae to the benthic first crab stage was stimulated by short-term exposure to both natural marsh sediments and water overlying a marsh containing older $U$. pugnax. In all 3 experiments, megalopae exposed to both natural seawater and marsh sediments for a $3 \mathrm{~d}$ period showed a greater response than megalopae exposed to only natural seawater. However, differences in molting response between the natural seawater and natural seawater plus sediment treatments disappeared within $2 \mathrm{~d}$, suggesting that both waterborne and sediment-derived cues were effective at stimulating molting

Either 1 or $3 \mathrm{~d}$ of exposure to cues in the field (sediment-derived or waterborne) was sufficient to increase

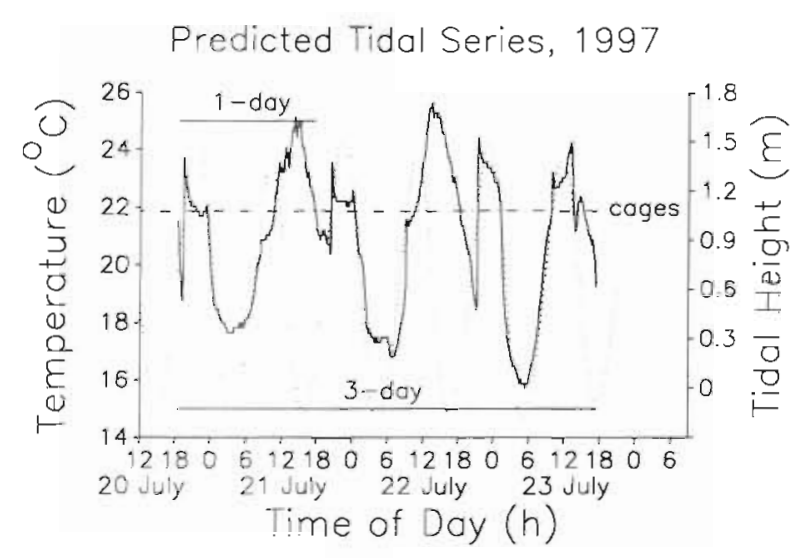

Fig. 4. Uca pugnax. Temperature within field cages and tidal height for 1997 experiment. Both the $1 \mathrm{~d}$ and $3 \mathrm{~d}$ duration of cue exposure treatments were initiated on $20 \mathrm{July}$. Temperatures (solid line) were sampled every $40 \mathrm{~s}$ with a $12 \mathrm{~cm}$ probe (Optic Stow Away, Onset Computers) positioned into the water at the petri dish bottom of a cage. Predicted tidal heights (dotted line) were based upon Newport, Rhode Is!and (USA) and phase-aligned with the field site based upon the evening flood tice. The tidal height of the field cages is indicated by the dashed line 
marsh that waterborne cues can effect a response. These questions will be addressed in future studies

The presence of sediment from a sandflat adjacent to the marsh had no significant effect on molting of megalopae caged in the marsh. The instability of the latticework structure, the large amount of sand deposited in the cages, and the death and dismemberment of megalopae in the cages suggest that the sandflat environment may be too physically unstable for settling megalopae. However, the fresh sand did not present a negative cue for molting of megalopae caged in the marsh. If Uca pugnax megalopae settle on the sandflat. the lack of other habitat features (physical structure of marsh grass, chemical cues from adult crabs) may lead megalopae to choose not to remain on the sandflat. In contrast, megalopae of the beach-dwelling sand fiddler crab Uca pugilator and ghost crab Ocypode quadrata may settle in beach habitats, environments physically more unstable than salt marshes. If those megalopae can move with breaking waves to higher intertidal elevations, or climb upward after burial by sand, they may avoid being damaged.

To minimize differences in temperature experienced by control megalopae and megalopae in cages in the field, we added a field control treatment in 1997. Megalopae were enclosed in glass jars containing filtered seawater, preventing contact with any natural chemical cues associated with the saltmarsh, but otherwise exposing megalopae to similar conditions of light and temperature to which megalopae in the mesh cages were exposed. However, megalopae in the jars likely did not experience the same abrupt rise in temperature during flood tide as did the megalopae in the cages (Fig. 4), although the temperature of water in the jars reached similar levels as did water in the cages. Nonetheless, temperatures rarely reached $26^{\circ} \mathrm{C}$, the temperature continuously experienced by the laboratory control megalopae. The virtually identical molting frequency of laboratory and field control megalopae in 1997 (Fig. 3) suggests that water temperature in this range did not strongly influence molting.

The magnitude of megalopal response to a $3 \mathrm{~d}$ exposure to marsh cues differed between the 2 years, being lower in 1997 (Figs. 2 \& 3). The proportion of megalopae molting in the laboratory control treatment was also higher in 1996, perhaps reflecting a lower ability of those megalopae to delay molting without marsh cues. The difference in molting frequency between years may be due to different larvae being used in the experiments. Different batches of crustacean larvae of the same species reared in a similar fashion may differ in settlement response to substratum cues $\left(\mathrm{O}^{\prime} \mathrm{Connor}\right.$ \& Richardson 1998). In addition, the fact that control megalopae were held at different salinities (25 in 1996, 30 in 1997) may have influenced molting response.
Uca pugnax megalopae settle in marshes occupied by older conspecifics (O'Connor 1993). Therefore, they appear to have the ability to recognize appropriate marsh habitat. Once in the marsh, molting is advanced One advantage of molting rapidly to the benthic crab stage could be to avoid predation by both fish (Johnson et al. 1990) and crabs. Fiddler crabs readily consume megalopae, both blue crab (Welch et al. 1997) and conspecific (Gregg \& $\mathrm{O}^{\prime}$ Connor unpubl.), but first stage crabs are consumed less (Gregg \& $O^{\prime}$ Connor unpubl.). The advantages of settling gregariously, such as for future mating and reproduction, may outweigh any disadvantages of cannibalism during a short temporal window.

Sediment freshly collected from a marsh with $U_{c a}$ pugnax adults stimulated molting, as did seawater overlying the marsh (= muffled treatment). Fresh sand from an adjacent sandflat, with resident microbes and small infauna, had no effect on molting of $U$. pugnax megalopae caged in the marsh. Therefore, something specific to the marsh was the stimulatory factor. Biological components of the marsh to which $U$. pugnax megalopae may respond include the marsh grass Spartina alterniflora, adult $U$. pugnax, and microbial assemblages. It is unlikely that chemicals from marsh grasses alone stimulated molting, as substances leached from S. alterniflora have no significant effect on molting of $U$. pugnax megalopae in laboratory experiments (O'Connor \& Gregg 1998). In contrast, sediments collected near adult burrows stimulate molting of $U$. pugilator megalopae (Christy 1989), as do sediments incubated with adult crabs prevented from directly contacting the sediments $\left(\mathrm{O}^{\prime}\right.$ Connor 1991). This suggests that adult crabs influence the chemical composition of the sediments, perhaps indirectly. In addition, water-soluble chemicals released by adult crabs stimulate molting of $U$. pugnax megalopae $\left(\mathrm{O}^{\prime} \mathrm{Connor} \&\right.$ Gregg 1998). Therefore, sediment-derived cues may be microorganisms associated with salt-marsh sediments, or water-soluble molecules that have been adsorbed by microbial assemblages and associated exopolymers (Decho 1990). Molecules in microbial biofilms may include those released by conspecific adult crabs.

Adult crabs may be an indicator of appropriate habitat for settlement and metamorphosis (molting) of fiddler crab megalopae. Adult crabs are also habitat indicators for other gregarious crab species. For example, megalopae of the intertidal anomuran Petrolisthes cinctipes settle near older conspecifics (Jensen 1989), and delay settlement for 2 to $3 \mathrm{wk}$ in the laboratory if no conspecific adults are present (Jensen 1991). Adultconditioned seawater shortens the duration of the megalopal stage of the gregarious anomurans Pagurus maclaughlinae and Paguristes tortugae (Harvey 1996). 
Megalopae of crabs not easily classified as gregarious or non-gregarious, such as intertidal crabs of the family Xanthidae, have complex molting responses. Panopeus herbstii megalopae molt in response to natural rock/shell substrate; the brown alga Fucus vesiculosus, which grows associated with rocks; biofilms on structural mimics of rock and algae; and exudates from adult conspecifics (Weber \& Epifanio 1996). It is possible that biofilms on the mimics contained watersoluble molecules from adult crabs, because the biofilms were allowed to develop in adult habitat. Megalopae of another xanthid crab Rhithropanopeus harrisii also molt in response to adult-conditioned seawater (Fitzgerald et al. 1998).

For non-gregarious decapods examined to date, however, cues stimulating settlement and molting seem to be associated with organisms that provide structural refuge for newly molted juveniles. Blue crab Callinectes sapidus megalopae do not molt in response to water-soluble chemicals from conspecific adults (Forward et al. 1994), but molt sooner in the presence of water-soluble cues from marshes (Wolcott \& DeVries 1994), in particular the marsh grass Spartina alterniflora (Forward et al. 1996). Chemical cues from other vegetation, such as seagrasses and macroalgae, also stimulate molting (Brumbaugh \& McConaugha 1995, Forward et al. 1996). Humic acids stimulate molting of $C$. sapidus megalopae (Forward et al. 1997), but their effect on molting of $U_{C a}$ pugnax megalopae is unknown. Postlarvae of spiny lobsters Panulirus argus and the American lobster Homarus americanus settle in response to macroalgae (Botero \& Atema 1982, Herrnkind \& Butler 1986) although timing of molting is not affected (Butler \& Herrnkind 1991). In addition, structurally complex substrates stimulate settlement and molting of glaucothoe of the red king crab Paralithodes camtschaticus (Stevens \& Kittaka 1998).

After completing a successful voyage through the gauntlet of a planktonic existence, larvae face a critical transition to the benthic phase of the life cycle. Larvae must locate an appropriate benthic habitat and metamorphose to the juvenile form. Our field caging technique allows experimental manipulation of variables to examine cues facilitating this transition. Although the technique was developed for use with crustacean larvae, it could be modified for experiments with larvae of other taxa,

Acknowledgements. We are very grateful to our students for their hard work: Paul Bourdeau. Peter Calatozzo, Danielle Cigliano, Richard Froio, Jenni. Manfredi, Erica May, and especially Amanda Gregg. We also thank the staff of Demarest Lloyd State Park and the Lloyd Center for Environmental Studies for allowing us to perform the experiments on their property.

\section{LITERATURE CITED}

Abelson A, Denny M (1997) Settlement of marine organisms in flow. Annu Rev Ecol Syst 28:317-339

Botero L, Atema J (1982) Behavior and substrate selection during larval settling in the lobster Homarus americanus. J Crustac Biol 2:59-69

Brumbaugh RD, MCConaugha JR (1995) Time to metamorphosis of blue crab Callinectes sapidus megalopae: effects of benthic macroalgae. Mar Ecol Prog Ser 129:113-118

Burke RD (1983) The induction of metamorphosis of marine invertebrate larvae: stimulus and response. Can J Zool 61. $1701-1719$

Butler MJ IV, Hermkind WF (1991) Effect of benthic microhabitat cues on the metamorphosis of pueruli of the spiny lobster Panulirus argus. J Crustac Biol 11:23-28

Butman CA (1987) Larval settlement of soft-sediment invertebrates: the spatial scales of pattern explained by active habitat selection and the emerging role of hydrodynamical processes. Oceanogr Mar Biol Annu Rev 25: $113-165$

Christy JH (1989) Rapid development of megalopae of the fiddler crab Uca pugilator reared over sediment: implications for models of larval recruitment. Mar Ecol Prog Ser $57: 259-265$

Crisp DJ (1974) Factors influencing the settlement of marine invertebrate larvae. In: Grant PT, Mackie MA (eds) Chemoreception in marine organisms. Academic Press, New York, p 177-265

Decho AW (1990) Microbial exopolymer secretions in ocean environments: their role(s) in food webs and marine processes. Oceanogr Mar Biol Annu Rev 28:73-153

Eckman JE (1983) Hydrodynamic processes affecting benthic recruitment. Limnol Oceanogr 28:241-257

Fitzgerald TP, Forward RB Jr, Tankersley RA (1998) Metamorphosis of the estuarine crab Rhithropanopeus harrisit effect of water type and adult odor. Mar Ecol Prog Ser 165 $217-223$

Forward RB Jr, Frankel DAZ, Rittschof D (1994) Molting of megalopae from the blue crab Callinectes sapidus: effects of offshore and estuarine cues. Mar Ecol Prog Ser 113 $55-59$

Forward RB Jr, DeVries MC, Rittschof D, Frankel DAZ, Bischoff JP, Fisher CM, Welch JM (1996) Effects of environmental cues on metamorphosis of the blue crab Callinectes sapidus. Mar Ecol Prog Ser 131:165-177

Forward RB Jr, Tankersley RA, Blondel D, Rittschof D (1997) Metamorphosis of the blue crab Callinectes sapidus effects of humic acids and ammonium. Mar Ecol Prog Ser $157: 277-286$

Gaines S, Brown S, Roughgarden J (1985) Spatial variation in larval concentrations as a cause of spatial variation in settlement for the barnacle, Balanus glandula. Oecologia $67: 267-272$

Harvey AW (1996) Delayed metamorphosis in Florida hermit crabs: multiple cues and constraints (Crustacea: Decapoda: Paguridae and Diogenidae). Mar Ecol Prog Ser 141 $27-36$

Herrnkind WF, Butler MJ IV (1986) Factors regulating postlarval settlement and juvenile microhabitat use by spiny lobsters Panulirus argus. Mar Ecol Prog Ser 34:23-30

Hunt HL, Scheibling RE (1997) Role of early post-settlement mortality in recruitment of benthic marine invertebrates Mar Ecol Prog Ser 155:269-301

Jensen GC (1989) Gregarious settlement by megalopae of the porcelain crabs Petrolisthes cinctipes (Randall) and $P$. eriomerus (Stimpson). J Exp Mar Biol Ecol 131:223-231 
Jensen GC (1991) Competency, settling behavior, and postsettlement aggregation by porcelain crab megalopae (Anomura: Porcellanidae). J Exp Mar Biol Ecol 153:49-61

Johnson WS, Allen DM, Ogburn MV, Stancyk SE (1990) Shortterm predation responses of adult bay anchovies Anchoa mitchilli to estuarine zooplankton availability. Mar Ecol Prog Ser 64:55-68

Levin LA (1984) Life history and dispersal patterns in a dense infaunal polychaete assemblage: community structure and response to disturbance. Ecology 65:1185-1200

Meadows PS, Campbell JI (1972) Habitat selection by aquatic invertebrates. Adv Mar Biol 10:271-382

Morse DE (1990) Recent progress in larval settlement and metamorphosis: closing the gaps between molecular biology and ecology. Bull Mar Sci 46:465-483

NOAA (1996) Tide tables, high and low water predictions, east coast of North and South America, including Greenland. US Dept of Commerce, Washington, DC

NOAA (1997) Tide tables, high and low water predictions, east coast of North and South America, including Greenland. US Dept of Commerce, Washington, DC

O'Connor NJ (1991) Flexibility in timing of the metamorphic molt by fiddler crab megalopae Uca pugilator. Mar Ecol Prog Ser 68:243-247

O'Connor NJ (1993) Settlement and recruitment of the fiddler crabs Uca pugnax and $U$. pugilator in a North Carolina, USA, salt marsh. Mar Ecol Prog Ser 93:227-234

O'Connor NJ, Gregg AS (1998) Influence of potential habitat cues on duration of the megalopal stage of the fiddler $\mathrm{crab}$ Uca pugnax. J Crustac Biol 18:700-709

O'Connor NJ, Judge ML (1997) Flexibility in timing of molting of fiddler crab megalopae: evidence from in situ manipulation of cues. Mar Ecol Prog Ser 146:55-60

Editorial responsibility: Otto Kinne (Editor),

Oldendorf/Luhe, Germany
O'Connor NJ, Richardson DL (1998) Attachment of barnacle (Balanus amphitrite Darwin) larvae: responses to bacterial films and extracellular materials. J Exp Mar Biol Ecol 226 115-129

Pawlik JR (1992) Chemical ecology of the settlement of benthic marine invertebrates. Oceanogr Mar Biol Annu Rev 30:273-335

Raimondi PT (1988) Settlement cues and determination of the vertical limit of an intertidal barnacle. Ecology 69:400-407

Rodriguez SR, Ojeda FP, Inestrosa NC (1993) Settlement of benthic marine invertebrates. Mar Ecol Prog Ser 97: 193-207

Scheltema RS (1974) Biological interactions determining larval settlement of marine invertebrates. Thalassia Jugosl 10(1/2):263-296

Sokal RR, Rohlf FJ (1981) Biometry. WH Freeman and Company, New York

Stevens BG, Kittaka J (1998) Postlarval settling behavior, substrate preference, and time to metamorphosis for red king crab Paralithodes camtschaticus. Mar Ecol Prog Ser 167: 197-206

Weber JC, Epifanio CE (1996) Response of mud crab (Panopeus herbstii) megalopae to cues from adult habitat. Mar Biol 126:655-661

Welch JM, Rittschof D, Bullock TM, Forward RB Jr (1997) Effects of chemical cues on settlement behavior of blue crab Callinectes sapidus postlarvae. Mar Ecol Prog Ser 154:143-153

Wethey DS (1986) Ranking of settlement cues by barnacle larvae: influence of surface contour. Bull Mar Sci 39:393-400

Wolcott DL, DeVries MC (1994) Offshore megalopae of Callinectes sapidus: depth of collection, molt stage, and response to estuarine cues. Mar Ecol Prog Ser 109:157-163

Submitted: October 23, 1998; Accepted: January 26, 1999 Proofs received from author(s): May 3, 1999 